\title{
Return on investment in the implementation of energy-efficient solutions for facade insulation
}

\author{
Olga Gamaunova* and Tatiana Musorina \\ Peter the Great St.Petersburg Polytechnic University, 195251, Polytechnitcheskaya st 29, St.- \\ Petersburg, Russia
}

\begin{abstract}
In this article the technique of determination of payback period of investments taking into account capital costs and economy of means at the expense of implementation of energy saving actions for warming of external protecting designs is considered. Presented in the article the method of assessing the return on investment in the implementation of energy-efficient solutions of facade insulation is only evaluative. For more accurate calculations it is necessary to take into account the discount rate. Nevertheless, the main factors that have a positive impact on reducing the payback period of investments in the renovation of facades are identified. Only an integrated approach to improving the energy efficiency of buildings can not only reduce the cost of operation of buildings, but also provide a reduction in the payback period of investment in the implementation of energy efficiency measures.
\end{abstract}

\section{Introduction}

Constantly increasing tariffs for housing and communal services make more and more people think about energy saving. Today, $80 \%$ of the cost of housing and communal services - this is the cost of water, light and heat. Thus consumers pay all losses of resources. If on the newly constructed objects this problem is still being solved, then secondary housing, especially the old building, is almost not paid attention.

In this connection, it is of practical interest to determine the list of energy-saving measures in housing construction, as well as the effectiveness of their implementation.

The topic of energy efficiency is actively studied in modern institutions by both young professionals and experienced scientists. Develop, offer and implement new methods and materials [1-2]. Abroad, concern about energy saving resources is also relevant, in the regulations of many countries there are requirements for energy efficiency and standards of energy consumption by buildings are constantly decreasing [3-4].

To calculate the payback period of investments aimed at additional insulation of the exterior walls of an existing building, for example, an apartment building, the method of the given costs, described in detail in [5-7], is used.

For other types of energy-saving measures, annual savings can be obtained based on the analysis and evaluation of energy-saving design solutions [8-12].

* Corresponding author: gamayunova@inbox.ru 
The area where it is possible to quickly reduce the amount of fuel consumed and as a result, energy consumption and emissions into the atmosphere - it's housing, which according to various estimates consumes 30 to $40 \%$ of all energy [13-15]. To do this, it is sufficient to increase the regulatory requirements for the level of thermal insulation [14], to improve the degree of building automation when adjusting the parameters of the heat transfer fluid at the building entrance, to install exhaust heat heat recovery systems [16] and more efficient heating systems.

The purpose of the study is to rationale the need for energy-saving actions and to evaluate the payback period.

To achieve the goal it is necessary to decide the following tasks:

1. Determine the thermal characteristics of enclosing structures

2. Determine the minimum required thickness of the insulation to provide the required thermal resistance of the wall

3. Return on investment in facade insulation

\section{Materials and Methods}

To evaluate the return on investment in the implementation of energy efficient solutions must use the methods of construction of thermal physics.

Resistance to heat transfer of enclosing structures

The building envelope should have a certain value of the resistance to heat transfer, on which the costs of building maintenance and sanitary and hygienic conditions of the premises depend.

Let's consider a variant of warming of external walls of apartment houses of series OD, the most typical for St. Petersburg. Construction of houses of the OD series was conducted from 1959 to 1963 . Due to the design of the external wall panels, the houses of this series are the record holders for heat losses.

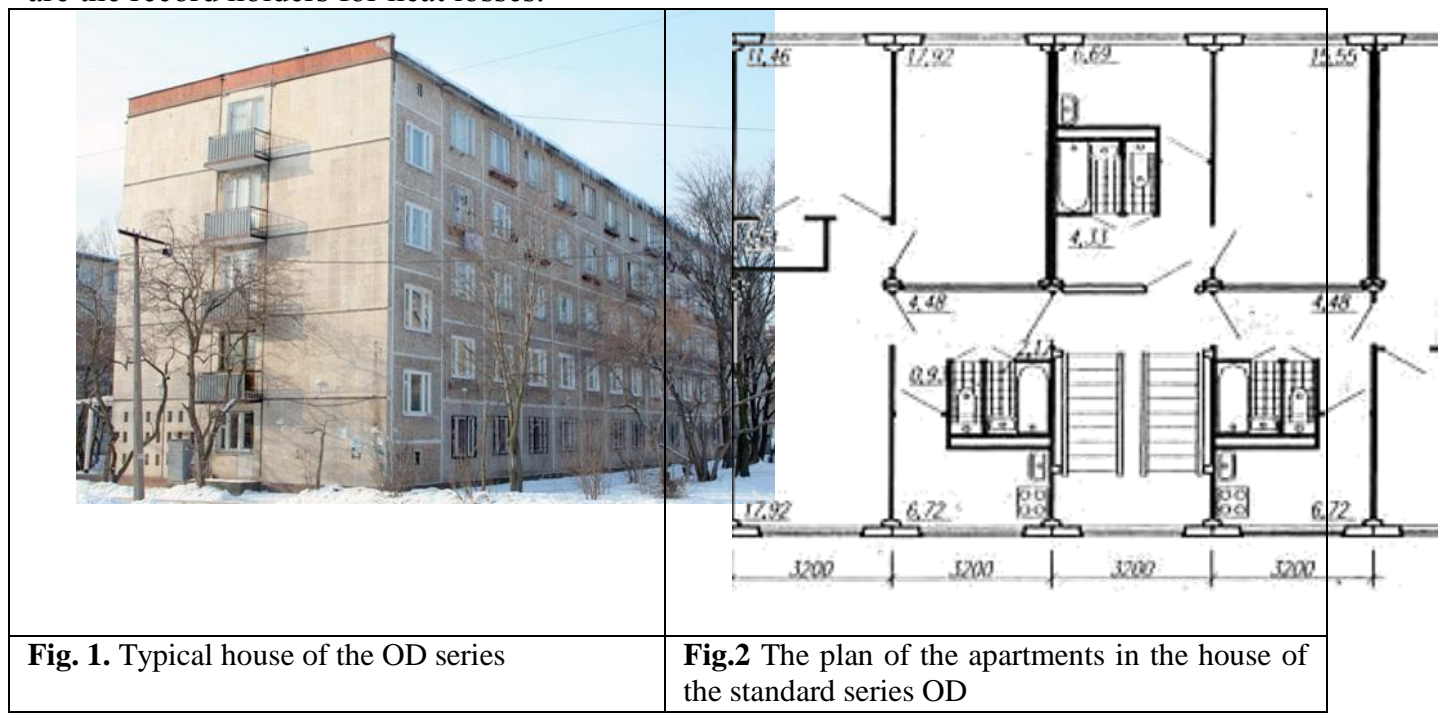

In the OD series, the exterior wall design is a three-layer hinged thin-walled panels consisting of an external reinforced concrete shell with edges along the contour, a mineral wool insulation board based on a phenolic bond, aerated concrete, foam glass, foam-coated and an internal reinforced cement-sandy plastering layer. 
Characteristic features of freezing panels are spots of moisture and mold, protruding on the interior surfaces of exterior walls with decreasing outdoor temperature. In some cases, during heavy frosts on the walls of frost and frost appears formed. Freeze through the panel and in the series of houses consideration OD with three-layer walls (on the fifth floor), but in many cases found freezing in any other area of the wall, on any floor.

In multi-layer walls the reason for freezing is the use of insulation with high humidity with insufficient thickness. This leads to wetting and subsidence of the insulation during operation. In some series of houses this is facilitated by the specific design features of the joints and deviations from the project. For example, houses a series of OD - filling dowel between the panels of heavy concrete.

Thermal insulation of freezing three-layer walls with a phenol-bonded mineral wool insulation is the replacement of insulation. The internal layer of the panel at the same time opens and removes damp insulation. It is necessary to check availability and a condition of a heater on all surface of the panel by means of sampling with the subsequent sealing of apertures. The cleaned cavity of the wall should be dried and tightly sealed with mineral wool bags wrapped with polymer film, the thickness of which should correspond to the width of the cavity. The opened area is sealed with a plaster mortar applied on a grid fixed on releases of reinforcement. At the opening of the cavity wall is that the facing faces of the ribs of the panels should not be destroyed. In table. 1 technical characteristics of typical projects of the OD series are presented [17-19].

Table 1. Technical characteristics of the model projects of the series OD

\begin{tabular}{|c|c|c|c|c|c|c|c|c|c|}
\hline \multirow[b]{2}{*}{$\begin{array}{l}\text { Ser } \\
\text { ies }\end{array}$} & \multicolumn{3}{|c|}{ Number } & \multicolumn{3}{|c|}{ Planning } & \multirow{2}{*}{$\begin{array}{c}\mathrm{Li} \\
\text { ving } \\
\text { space, } \\
\mathrm{m}^{2}\end{array}$} & \multirow[b]{2}{*}{$\begin{array}{l}\text { Useful } \\
\text { area of the } \\
\text { house, } m^{2}\end{array}$} & \multirow{2}{*}{$\begin{array}{c}\text { Cubi } \\
\text { cal } \\
\text { content, } \\
\mathrm{m}^{2} \\
\end{array}$} \\
\hline & $\begin{array}{c}\mathrm{S} \\
\text { ectio } \\
\mathrm{n}\end{array}$ & $\begin{array}{c}\mathrm{Fl} \\
\text { oors }\end{array}$ & $\begin{array}{l}\text { ro } \\
\text { oms }\end{array}$ & $\begin{array}{c}1 \\
\text { ro } \\
\text { om }\end{array}$ & $\begin{array}{c}2 \\
\text { rooms }\end{array}$ & $\begin{array}{c}3 \\
\text { rooms }\end{array}$ & & & \\
\hline $\begin{array}{r}\mathrm{O} \\
\mathrm{D}-4\end{array}$ & 4 & 5 & 60 & 10 & 40 & 10 & $\begin{array}{c}18 \\
76^{18}\end{array}$ & 2718 & 9860 \\
\hline $\begin{array}{r}\mathrm{O} \\
\mathrm{D}-6\end{array}$ & 6 & 5 & 90 & 15 & 60 & 15 & $\begin{array}{r}28 \\
44^{28}\end{array}$ & 4077 & $\begin{array}{l}1479 \\
0\end{array}$ \\
\hline
\end{tabular}

In houses with three-layer walls warming of horizontal joints should be made removal of the crude or sifted insulation, drying of a cavity with replacement of a insulation and consolidation of a joint by expanded clay concrete of quality class number 50 . Preliminary preparatory work is carried out, consisting in chipping the edge of the wall panel and concrete sealing of the ceiling at the wall to a depth of $100 \mathrm{~mm}$ with a plot width of about $100 \mathrm{~mm}$ (the floor is previously disassembled along the wall). The padding of a plaster layer of the wallboard on the plot with a width of $200 \mathrm{~mm}$ from the horizontal joint. In some cases, if the freezing of vertical angular joints can not be eliminated by the above method, a bevel device made of expanded clay concrete can be recommended. Bevel should be arranged triangular cross-section with the size of the legs $25 \mathrm{~cm}$. Thermal and physical characteristics of the materials that consist the exterior walls of houses the OD series are shown in table.2. Exterior walls - reinforced concrete wall panel, insulated foaming agent and a thickness of $300 \mathrm{~mm}$.

Table 2. Thermophysical characteristics materials of the exterior walls of the series OD

\begin{tabular}{|c|c|c|c|}
\hline Material & $\begin{array}{c}\text { Thickness } \\
\text { layer }(\delta), \\
\mathrm{mm}\end{array}$ & $\begin{array}{c}\text { Density } \\
(\rho), \mathrm{kg} / \mathrm{m}^{3}\end{array}$ & Thermal conductivity $(\lambda), \frac{W}{\mathrm{~m} \cdot{ }^{\circ} \mathrm{C}}$ \\
\hline Reinforsconcrete & 300 & 2500 & 1.7 \\
\hline Foaming agent & 10 & 500 & 0.15 \\
\hline
\end{tabular}


Thermal calculation showed that the thermal resistance of the exterior walls of the wall is much lower than required $\left(\mathrm{R}_{0}=0.4016 \mathrm{~m}^{2} \times{ }^{\circ} \mathrm{C} / \mathrm{W}<\mathrm{Rreq}=3.0786 \mathrm{~m}^{2} \times{ }^{\circ} \mathrm{C} / \mathrm{W}\right)$. The most obvious way to improve the thermal characteristics of the existing design is a competent selection of insulation [20-21].

For example, consider the mineral wool insulation ISOVER Warm walls. Thermal conductivity $0.036 \mathrm{~W} /\left(\mathrm{m}^{2} \times{ }^{\circ} \mathrm{C}\right)$.

The minimum permissible (required) thermal resistance of the thermal insulation material is calculated by the formula:

$$
R_{i n s}^{r e q}=R_{r e q}-\left(R_{\text {int }}+R_{e x t}+\sum R_{i}\right)=3.0786-0.4016=2.6770 \quad \frac{m^{2} \cdot{ }^{\circ} \mathrm{C}}{W}
$$

The thickness of the insulation is:

$$
\delta_{\text {ins }}^{r e q}=\lambda_{\text {ins }} \cdot R_{\text {ins }}^{\text {req }}=0.036 \cdot 2.6770=0.096 \mathrm{~m}=96 \mathrm{~mm}
$$

Determine the thermal resistance of the wall under the condition that the total thickness of the insulation will be equal to $100 \mathrm{~mm}$ :

$$
\begin{aligned}
& R_{0}^{i n s}=R_{\mathrm{int}}+R_{\text {ext }}+\sum R_{i}^{\text {ins }}= \\
& =\frac{1}{8.7}+\frac{1}{23}+0.18+\frac{0,1}{0.036}=3.113 \frac{\mathrm{m}^{2} \cdot{ }^{\circ} \mathrm{C}}{W}
\end{aligned}
$$

From the result it can be concluded that $\mathrm{R}_{0}=3.113 \mathrm{~m}^{2} \times{ }^{\circ} \mathrm{C} / \mathrm{W}>\mathrm{R}_{\text {req0 }}=3.0786$ $\mathrm{m}^{2} \times{ }^{\circ} \mathrm{C} / \mathrm{W}$, therefore, the thickness of the insulation is chosen correctly.

\section{Results and Discussion}

\section{Return on investment in facade insulation}

To calculate the payback period, we apply the method of reduced costs.

$$
\begin{aligned}
& \mathrm{P}_{1}=\mathrm{K}_{1}+\mathrm{O}_{1} \cdot \mathrm{T} ; \\
& \mathrm{P}_{2}=\mathrm{K}_{2}+\mathrm{O}_{2} \cdot \mathrm{T} ;
\end{aligned}
$$

$\mathrm{P}_{1}, \mathrm{P}_{2}$ - costs of capitalization and operation of external walls, given to $1 \mathrm{~m}^{2}$ of area, $\mathrm{rub} / \mathrm{m}^{2}$; $\mathrm{K}_{1}$ - capital costs for the construction $1 \mathrm{~m}^{2}$ exterier walls, rubles $/ \mathrm{m}^{2}$;

$\mathrm{K}_{2}$ - capital costs for additional insolation, rubles $/ \mathrm{m}^{2}$;

$\mathrm{O}_{1}$ - operating costs, taking into account the loss of thermal energy through $1 \mathrm{~m}^{2}$ the exterier wall for one heating season before the insulation, rubles $/ \mathrm{m}^{2}$;

$\mathrm{O}_{2}$ - operating costs, taking into account the loss of thermal energy through $1 \mathrm{~m}^{2}$ exterier wall for one heating season after wall insulation, rubles $/ \mathrm{m}^{2} \cdot$ year;

$\mathrm{T}$ - time, counted in years.

The payback condition for the adopted model will be the equality of the reduced costs $\mathrm{P}_{1}$ and $\mathrm{P}_{2}$, i.e.: $\mathrm{P}_{1}=\mathrm{P}_{2}$

Or subject to equation (1), (2): $\mathrm{K}_{1}+\mathrm{O}_{1} \cdot \mathrm{T}=\mathrm{K}_{2}+\mathrm{O}_{2} \cdot \mathrm{T}$

Given that we are considering an existing building, then $\mathrm{K}_{1}=0$ :

$$
\mathrm{O}_{1} \cdot \mathrm{T}=\mathrm{K}_{2}+\mathrm{O}_{2} \cdot \mathrm{T}
$$

Then from equation (3) you can calculate the payback period of an energy-saving solution:

$$
T=\frac{K_{2}}{O_{1}-O_{2}}=\frac{\Delta K}{\Delta O}
$$

$\Delta \mathrm{K}$ - the difference between capital expenditures on $1 \mathrm{~m}^{2}$ extrier wall;

$\Delta \mathrm{O}$ - the difference in heat energy losses through $1 \mathrm{~m}^{2}$ extrier wall before carrying out actions for warming of facades of the existing building $\left(\mathrm{O}_{1}\right)$ and after warming $\left(\mathrm{O}_{2}\right)$.

Note that the payback period calculated by the formula (4) is obtained without taking into account: 
- growth of tariffs for thermal energy;

- interest on the loan (in the case of using borrowed funds to carry out activities for the insulation of the exterior walls of the building);

- discounting of the future cash receipts achieved as a result of implementation of energy saving action and reduction of losses of thermal energy on heating.

For this reason, the payback period calculated by formula (4) can only be considered as an estimate.

Determine the payback period of investment in the insulation of the external walls of houses series OD. To do this, we calculate the capital costs and cost savings through the implementation of energy-saving measures for the insulation of external walls.

Capital costs for insulation of external walls of houses

For calculation we will consider that warming of facades will occur at the expense of borrowed funds; the credit is taken for 2 years ( 24 months). Then, with annuity monthly payments, the total investment in energy saving will be determined by the formula:

$$
\Delta \mathrm{K}=\mathrm{m} \cdot \mathrm{A} \cdot \Delta \mathrm{K}
$$

$\mathrm{m}$ - number of loan repayment periods, month;

$\mathrm{A}$ - annuity ratio;

$\Delta \mathrm{K}$ - own funds of the contractor (investment without loan payments), rub.

Annuity ratio (A) is calculated by the formula:

$$
A=\frac{p_{c r} \cdot\left(1+p_{c r}\right)^{m}}{\left(1+p_{c r}\right)^{m}-1}=\frac{0.013 \cdot(1+0.013)^{24}}{(1+0.013)^{24}-1}=0.049
$$

$\mathrm{P}_{\mathrm{cr}}-$ monthly interest rate of the Bank on the credit, expressed in hundredths of shares.

$$
p_{c r}=\frac{p_{c r}}{12} \cdot \frac{1}{100}=\frac{15.7}{12} \cdot \frac{1}{100}=0.013
$$

Since we consider the existing building then: $\Delta \mathrm{K}=\mathrm{K}_{2}-\mathrm{K}_{1}=\mathrm{K}_{2}$,

Capital costs for additional insulation of the exteriorr wall of the existing building will take equal to $1530 \mathrm{rubles} / \mathrm{m}^{2}$. This amount includes the cost of insulation-160 rubles $/ \mathrm{m}^{2}$ (Isover Warm Walls, 1170x610x100 mm), $270 \mathrm{rubles} / \mathrm{m}^{2}$ is the cost of dry mixes; 60 rubles $/ \mathrm{m}^{2}$ - the cost of disk-shaped dowel; 40 rubles $/ \mathrm{m}^{2}$ - the cost of profiles; 1000 rubles $/ \mathrm{m}^{2}$ - the cost of a full cycle of construction and installation works. Then we get: $\Delta \mathrm{K}$ $=24 \cdot 0.049 \cdot 1530=1799.28 \mathrm{rub}$.

Cost savings due to thermal insulation of external walls of buildings.

For 2018, the cost of thermal energy $\left(\mathrm{c}_{\mathrm{G}}\right)$ is set at 1678.72 rubles/Gcal. The number HDD in St. Petersburg is $4796{ }^{\circ} \mathrm{C} \cdot$ day.

For calculation of transmission losses of thermal energy through the exterior walls is convenient to use the value of the inverse resistance to heat transfer, the heat transfer coefficient (V):

$$
\mathrm{V}=\frac{1}{\mathrm{R}_{0}}
$$

In this case, the heat transfer coefficient of the outer walls without insulation $\left(\mathrm{V}_{1}\right)$ is:

$$
V_{1}=\frac{1}{R_{0}^{\text {initial }}}=\frac{1}{0.4016}=2.49 \frac{W}{m^{2} \cdot{ }^{\circ} \mathrm{C}}
$$

Required heat transfer resistance for exterior walls of residential buildings in relation to climatic conditions of St. Petersburg ( $\mathrm{HDD}=4796{ }^{\circ} \mathrm{C} \cdot$ days) paвно $\mathrm{R}_{\mathrm{req}}=3.08 \mathrm{~m}^{2} \times{ }^{\circ} \mathrm{C} / \mathrm{W}$, which corresponds to the heat transfer coefficient $\mathrm{V}_{2}$ :

$$
V_{2}=\frac{1}{R_{0}^{\text {req }}}=\frac{1}{3.08}=0.325 \frac{W}{m^{2} \cdot{ }^{\circ} \mathrm{C}}
$$


Then, taking into account the conversion factors (0.024 and 1163), the annual savings of $\Delta \mathrm{O}$ funds achieved as a result of the work on the insulation of the facades of the existing building will be determined by the formula:

$$
\begin{aligned}
& \Delta O=\left(V_{1}-V_{2}\right) \frac{0.024 \cdot H D D}{1163} \cdot c_{G}= \\
& =(2.49-0.325) \frac{0.024 \cdot 4796}{1163}=1678.72=359.71\left(\frac{r u b .}{m^{2}}\right)
\end{aligned}
$$

From (9) it follows that under the given climatic conditions and the option of insulation of the external walls, the rate of return of the invested funds depends only on the cost of heating $\left(\mathrm{c}_{\mathrm{G}}\right)$ and the dynamics of growth of tariffs for thermal energy. The dynamics of growth of tariffs for thermal energy in St. Petersburg is presented in the table. 3.

Table 3. Dynamics of growth of tariffs for thermal energy in St. Petersburg in 2008-2018

\begin{tabular}{|c|c|c|}
\hline Year & $\begin{array}{c}\text { Price, } \\
\text { RUB/Gcal }\end{array}$ & $\begin{array}{c}\text { Increase in the cost of thermal energy in \% compared to the previous } \\
\text { year (heating period), } \Delta \mathrm{c}_{\mathrm{G}}\end{array}$ \\
\hline 2008 & 650.00 & - \\
\hline 2009 & 795.73 & $+22.4 \%$ \\
\hline 2010 & 931.00 & $+17.0 \%$ \\
\hline 2011 & 1050.00 & $+12.8 \%$ \\
\hline 2013 & 1175.00 & $+11.9 \%$ \\
\hline 2014 & 1351.25 & $+15.0 \%$ \\
\hline 2015 & 1408.01 & $+4.2 \%$ \\
\hline 2016 & 1541.78 & $+9.5 \%$ \\
\hline 2017 & 1621.95 & $+5.2 \%$ \\
\hline 2018 & 1678.72 & $+3.5 \%$ \\
\hline
\end{tabular}

As can be seen from table 3, for the period under review (from 2008 to 2018), the average relative growth of tariffs for thermal energy in the year of $\Delta \mathrm{c}_{\mathrm{G}}$ was $11.3 \%$. Therefore, the average annual growth of tariffs for thermal energy will be equal to 0.113 .

Discounting future cash flows (i) will produce at the rate of refinancing of the Central Bank of the Russian Federation $(7.5 \%)$, i.e. the parameter $i$ in the calculation of the payback period will take equal to 0.075 . Get:

$$
T=\frac{\ln \left(1+\frac{\Delta K}{\Delta O} \cdot \frac{r-i}{1+i}\right)}{\ln \left(\frac{1+r}{1+i}\right)}=\frac{\ln \left(1+\frac{1799.28}{359.71} \cdot \frac{0.113-0.075}{1+0.075}\right)}{\ln \left(\frac{1+0.113}{1+0.075}\right)}=4.7 \text { years }
$$

Given the economic and tariff situation in Russia, the return on investment in the insulation of facades of existing buildings in relation to the climatic conditions of St. Petersburg will be about 5 years.

Factors that have a positive impact on reducing the payback period of investment in the renovation of facades are:

* dynamics of growth of tariffs for thermal energy (r);

* reduction of the Bank's interest rates on the loan;

- the reduction of inflation or the risk (i);

* reducing the cost of capital costs for insulation (can lead to deterioration of the quality of construction and installation works).

As can be seen from table"since 2015, the dynamics of tariff growth has significantly decreased. In 2015-2018, the average tariff growth was 5.6\% (i.e. the average annual growth of tariffs for thermal energy will be 0.056 ). With this value, the payback period will be: 


$$
T=\frac{\ln \left(1+\frac{\Delta K}{\Delta O} \cdot \frac{r-i}{1+i}\right)}{\ln \left(\frac{1+r}{1+i}\right)}=\frac{\ln \left(1+\frac{1799.28}{359.71} \cdot \frac{0.056-0.075}{1+0.075}\right)}{\ln \left(\frac{1+0.056}{1+0.075}\right)}=5.2 \text { years }
$$

If, on the contrary, to consider the dynamics of growth of tariffs for thermal energy in 2009-2014, the average tariff growth was $15.82 \%$. Then, all other things being equal, the payback period will be about 5 years:

$$
T=\frac{\ln \left(1+\frac{\Delta K}{\Delta O} \cdot \frac{r-i}{1+i}\right)}{\ln \left(\frac{1+r}{1+i}\right)}=\frac{\ln \left(1+\frac{1799.28}{359.71} \cdot \frac{0.1582-0.075}{1+0.075}\right)}{\ln \left(\frac{1+0.1582}{1+0.075}\right)}=4.4 \text { years }
$$

If assume that the $\mathrm{CBR}$ refinancing rate will decrease from $7.5 \%$ to $7 \%$ the payback period will be:

$$
T=\frac{\ln \left(1+\frac{\Delta K}{\Delta O} \cdot \frac{r-i}{1+i}\right)}{\ln \left(\frac{1+r}{1+i}\right)}=\frac{\ln \left(1+\frac{1799.28}{359.71} \cdot \frac{0.113-0.07}{1+0.07}\right)}{\ln \left(\frac{1+0.113}{1+0.07}\right)}=4.6 \text { years }
$$

Similarly, it is possible to continue analyzing the factors that affect the payback period of investments in the implementation of energy-efficient solutions for facade insulation. This will help determine which of the factors has the strongest impact on reducing or increasing the payback period, and take this fact into account when implementing energysaving measures in the reconstruction of buildings.

Presented in the article the method of assessing the return on investment in the implementation of energy-efficient solutions of facade insulation is only evaluative. For more accurate calculations it is necessary to take into account the discount rate.

It should also be taken into account that the insulation of the facades of buildings of the old housing stock is most effective in combination with the glazing of loggias, balconies, installation of modern Windows, thermostats, etc.Only an integrated approach to improving the energy efficiency of buildings can not only reduce the cost of operation of buildings, but also provide a reduction in the payback period of investment in the implementation of energy efficiency measures.

\section{Conclusions}

As a result of calculations the following results are obtained:

In OD series houses the thermal resistance of walls $\mathrm{R}_{0}=0.4016 \mathrm{~m}^{2} \times{ }^{\circ} \mathrm{C} / \mathrm{W},\left(\mathrm{R}_{\mathrm{req}}=3.0786\right.$ $\left.\mathrm{m}^{2} \times{ }^{\circ} \mathrm{C} / \mathrm{W}\right)$.

The minimum required thickness of the insulation is determined by calculation, which will provide the required thermal resistance of the wall (for mineral wool insulation ISOVER Warm walls this value was $96 \mathrm{~mm}$, rounded to $100 \mathrm{~mm}$ ).

Based on the parameters of the heating period, the cost of additional insulation of facades and operating costs for heating, the optimal thickness of the additional layer of insulation is determined, at which the payback period takes a minimum value.

\section{References}

1. Gagarin V.G., Pastushkov P.P. AVOK. 2, 26-29 (2014) 
2. Gagarin V.G., Pastushkov P.P. Building materials, equipment, technologies of the XXI century. 6, C. 7-9 (2013)

3. Kurochkina K.Yu., Gorshkov A.S. Construction of Unique Buildings and Structures. 4 (31), 220-231 (2015)

4. Gubina I.A., Gorshkov A.S. Construction of Unique Buildings and Structures. 4 (31), 209-219 (2015)

5. Gonzalez, M., Machado, R., Gonzalez, J. American Society of Mechanical Engineers, Pressure Vessels and Piping Division (Publication) PVP 6 (PARTS A AND B). 905-911 (2011)

6. Vatin N.I., Nemova D.V., Rymkevich P.P., Gorshkov A.S. Magazine of Civil Engineering. 8 (34), 4-14 (2012)

7. Gorshkov A.S. Building materials, equipment, technologies of the XXI century. 7 (186), 26-35 (2014)

8. Sormunen P. Magazine of Civil Engineering. 1, 7-8 (2010)

9. Cheng Y., Nin J., Gao N. Building and Environment. 47, 13-22 (2012)

10. Gorshkov A.S., Rymkevich P.P. Building materials, equipment, technologies of the XXI century. 9 (188), 40-45 (2014)

11. Gorshkov A.S. VESTNIK MGSU. 12, 136-146 (2015)

12. Gorshkov A.S.., Musorina, T.A., Rakova, K.M. Building materials, equipment, technologies of the XXI century. 7-8 (222-223), 21-27 (2017)

13. Gorshkov A.S. Vatin N.I., Rymkevich P.P., Kydrevich O.O. Magazine of Civil Engineering. 2 (78), 65-75 (2018)

14. Kornienko S.V., Vatin N.I., Petrichenko M.R., Gorshkov A.S. Construction of Unique Buildings and Structures. 6 (33), 19-33 (2015)

15. Korniyenko S.V., Vatin N.I., Gorshkov A.S. Magazine of Civil Engineering. 4 (64), 1025 (2016).

16. Nemova D.V., Vatin N.I., Petrichenko M.R., Kornienko S.V., Gorshkov A.S. Construction of Unique Buildings and Structures. 6 (45), 102-114 (2016)

17. Statsenko E.A., Ostrovaia A.F., Musorina T.A., Kukolev M.I., Petritchenko M.R. Magazine of Civil Engineering. 8 (68), 86-91 (2016)

18. Musorina T.A., Gamayunova O.S., Petrichenko M.R. VESTNIK MGSU. 12. 11 (110), 1269-1277 (2017)

19. Petrichenko M.R., Kotov E.V., Nemova D.V., Tarasova D.S., Sergeev V.V. Magazine of Civil Engineering. 1 (77), 130-140. (2018)

20. Nemova D.V., Spiridonova T.I., Kurazhova V.G. Construction of Unique Buildings and Structures. 1, 36-46 (2012)

21. Samuel Faye Gamtessa. Energy and Buildings. 57. 155-164 (2013) 